CENDEKIA UTAMA

P-ISSN 2252-8865

Jurnal Keperawatan dan

E-ISSN 2598-4217

Kesehatan Masyarakat

Vol 10,No 2 Januari, 2021

STIKES Cendekia Utama Kudus

Tersedia Online:

http://jurnal.stikescendekiautamakudus.ac.id

\title{
INTERAKSI TEMAN SEBAYA BERPENGARUH TERHADAP PERILAKU MEROKOK REMAJA KELAS IX DI SMP DAWAN KLUNGKUNG
}

\author{
I Gede Eka Pratama ${ }^{1}$, Komang Yogi Triana ${ }^{2}$, Ni Made Dwi Ayu Martini ${ }^{3}$ \\ ${ }^{1-3}$ Program Studi S1 Keperawatan STIKES Bina Usada Bali \\ Email: igedeekap2@gmail.com
}

\begin{abstract}
ABSTRAK
Remaja merupakan periode transisi perkembangan dari masa anak ke masa dewasa yang ditandai dengan ketidakmatangan emosional yang stabil serta sangat rentan terpengaruh oleh teman sebaya, salah satunya yaitu merokok. Penelitian ini bertujuan untuk mengetahui hubungan interaksi teman sebaya dengan perilaku merokok pada remaja putra kelas ix di SMP Negeri Kecamatan Dawan Kabupaten Klungkung. Jenis penelitian ini yaitu penelitian kuantitatif dengan menggunakan metode pendekatan cross-sectional. Penelitian ini menggunakan tehnik total sampling, sebanyak 127 responden. Instrument yang digunakan dalam penelitian ini yaitu kuesioner teman sebaya dan kuesioner perilaku merokok. Hasil yang didapatkan yaitu interaksi teman sebaya sebagian besar terpengaruh sebanyak 119 responden (93,7\%), sedangkan untuk perilaku merokok sebagian besar berperilaku merokok tinggi sebanyak 91 responden $(71,7 \%)$. Berdasarkan hasil penelitian dengan menggunakan uji korelasi spearman's rho didapat nilai $\mathrm{p}$ value 0,000 , yang artinya ada hubungan antara interaksi teman sebaya dengan perilaku merokok pada remaja putra. Peran teman sebaya diharapkan dapat menjadi sasaran dalam mencegah bertambahnya remaja yang merokok.
\end{abstract}

Kata Kunci: Interaksi Teman Sebaya, Perilaku Merokok, Remaja

\begin{abstract}
Adolescence is a period of developmental transition from childhood to adulthood characterized by stable emotional immaturity and is very susceptible to be influenced by peers, one of them is smoking. This study aimed to determine the correlation between peer interaction and smoking behavior of male adolescents at class IX of SMP Negeri Dawan District, Klungkung Regency.

This type of study was a quantitative study using a cross-sectional approach. This study used a total sampling technique of 127 respondents. The instruments used in this study were peer questionnaires and smoking behavior questionnaires. The results obtained that they mostly influenced bypeer interaction of 119 respondents (93.7\%), while for smoking behavior, most of them had high smoking behavior as many as 91 respondents (71.7\%). Based on the results of the study using the Spearman's rho correlation test, the $p$ value was 0,000, which means that there was a correlation between peer interaction and smoking behavior of male adolescents at class IX. The role of peers is expected to be a target in preventing the increase in adolescents who are smoking.
\end{abstract}

Keywords: Peer Interaction, Smoking Behavior, Adolescents 


\section{LATAR BELAKANG}

Masa remaja merupakan periode transisi perkembangan dari masa anak-anak ke masa dewasa yang ditandai oleh perubahan-perubahan fisik umum serta perkembangan kognitif dan sosial (Ratnaningsih et al., 2019). Remaja dikategorikan sebagai kelompok penduduk yang berusia 10-24 tahun (Yatim, 2015). Pada usia remaja perilaku merupakan salah satu proses pengembangan jati diri dimana banyak faktor yang mempengaruhi usia tersebut diantaranya, kematangan mental, emosi dan fisik (Lailatul et al., 2015).

Kelompok remaja adalah kelompok yang sangat berisiko tinggi terhadap dunia luar yang pada umumnya memiliki pengaruh buruk salah satunya yaitu merokok, karena di usia remaja atau usia yang belum memiliki kematangan emosional yang stabil sangat rentan terpengaruh terhadap kelompok sebayanya (Lailatul et al., 2015). Pada era globalisasi seperti sekarang ini banyak sekali pergaulan yang menjerumuskan remaja ke hal-hal yang bersifat negatif seperti pengunaan obat-obat terlarang, minum-minuman keras, dan salah satu yang paling sering dilakukan oleh para remaja adalah merokok. Para remaja biasanya merokok di lingkungan rumah, sekolah, warung makan, halte bus dan tempat-tempat lainnya. Walaupun remaja dilarang untuk merokok, tetapi mereka tetap saja melanggar larangan tersebut(Soetjiningsih, 2018).

WHO (World Health Organization) memperkirakan bahwa persentase penduduk dunia yang mengonsumsi tembakau mencapai 57\% pada penduduk Asia dan Australia (WHO, 2015). Prevalensi perokok secara berturut-turut di Amerika Serikat dan Inggris pada remaja laki-laki adalah $25 \%$ dan $27 \%$ serta pada wanita adalah $21 \%$ dan $25 \%$ (Aminullah, 2018) . Riset Kesehatan Dasar (Riskesdas) tahun 2018 menyebutkan bahwa di Indonesia terjadi peningkatan angka perokok pada tahun 2007 hingga tahun 2013 sebesar 2,5\% dan terjadi penurunan pada tahun 2013 hingga tahun 2018 sebesar 2,1\%. Data Riskesdas tahun 2018 menunjukkan bahwa prevalensi perokok pada remaja usia 10-18 tahun mengalami peningkatan dari tahun 2013 (7,20\%) ke tahun 2018 (9,10\%). Angka tersebut masih sangat jauh dari target RPJMN (Rencana Pembangunan Jangka Menengah Nasional) tahun 2019 yaitu sebesar 5,4\%, dimana angka kejadian perokok pada laki-laki usia >15 tahun di tahun 2018 masih berada pada angka yang tinggi yaitu $(62,9 \%)$ dan masih menjadi prevalensi perokok tertinggi pada laki-laki di dunia (Riskesdas, 2018).

Hasil Riskesdas Provinsi Bali (2018), menunjukkan persentase penduduk umur 15-19 tahun yang merokok tiap harinya 20,2\%, dengan rata-rata jumlah konsumsi rokok sebanyak 8,2 batang perhari. Persentase perokok tertinggi ditemukan di Kota Denpasar 62,1\%, diikuti Kabupaten Tabanan 43,1\%, Klungkung 47,4\%, Badung 44,0\%, Jembrana 44,6\%, Gianyar 52,1\%, Bangli 38,0\%, Karangasem 51,0\% dan Kabupaten Buleleng 58,1\% (Dinkes, 2018). Berdasarkan data tersebut Kabupaten Klungkung menempati urutan ke-5 perokok untuk usia 15-19 tahun di Bali setelah Kabupaten Karangasem. Dinas Kesehatan Kabupaten Klungkung menyebutkan bahwa, berdasarkan hasil survei PISPK (Program Indonesia Sehat dengan Pendekatan Keluarga) yang telah dilakukan dari tahun 2018-2019 didapatkan jumlah perokok pada remaja dengan kelompok usia 13-21 tahun di Kecamatan Dawan yaitu mencapai 38,94\%. Dimana jumlah perokok di Kecamatan Dawan merupakan jumlah tertinggi pada kelompok remaja diantara empat kecamatan yang ada di Kabupaten Klungkung (Dinkes, 2019).

Berdasarkan hasil studi pendahuluan yang dilakukan pada tiga SMP Negeri yang ada di Kecamatan Dawan didapatkan jumlah siswa dari kelas VII-IX sebanyak 1.823 siswa dimana jumlah siswa laki-laki terbanyak terdapat di kelas IX dengan total 
keseluruhan pada 3 SMP yaitu sebanyak 186 siswa laki-laki. Hasil wawancara dan pengamatan langsung terhadap 15 siswa laki-laki dari ketiga SMP tersebut, bahwa 10 anak diantaranya berperilaku merokok dalam keseharian, dan 8 dari siswa tersebut mengatakan merokok untuk mengikuti pergaulan tanpa sepengetahuan dari orang tua. Hal yang sama juga dipaparkan oleh guru Bimbingan Konseling ( BK ) di ketiga sekolah tersebut, bahwa ditemukan hampir 10-12 siswa laki-laki dalam satu bulan yang tertangkap tangan tengah merokok di sekitar lingkungan sekolah. Hasil pengamatan di lapangan pada saat jam istirahat dan saat siswa pulang sekolah terdapat beberapa siswa yang merokok di warung dekat sekolah agar tidak terlihat oleh guru.

Penelitian ini bertujuan untuk mengetahui hubungan interaksi teman sebaya dengan perilaku merokok pada remaja putra di SMP Negeri Kecamatan Dawan Kabupaten Klungkung.

\section{METODE PENELITIAN}

Penelitian ini adalah kuantitatif dengan rancangan korelasional,. penelitian ini menggunakan metode pendekatan croos-sectional yang menekankan waktu pengukuran variabel independen dan dependen hanya satu kali pada satu saat (Nursalam, 2015). Sampel dipilih sebanyak 127 siswa SMP, dengan cara total sampling, menggunakan kriteria inklusi, yaitu; Siswa laki-laki kelas IX di tiga SMP Negeri Kecamatan Dawan Kabupaten Klungkung, Siswa yang merokok, Siswa yang kooperatif., Siswa yang bersedia menjadi responden yang telah menandatangani surat persetujuan menjadi responden atau inform consent. Data dianalisis menggunakan uji korelasi spearmen rank yaitu uji statistik yang ditujukan untuk mengetahui hubungan antara dua atau lebih variabel berskala ordinal (Sugiyono, 2017) dengan ketentuan jika nilai $\mathrm{p}<0.05$ maka dapat disimpulkan bahwa $\mathrm{H}_{0}$ ditolak serta $\mathrm{H}_{\mathrm{a}}$ diterima. Jika nilai $\mathrm{p} \geq 0,05$ maka dapat disimpulkan bahwa $\mathrm{H}_{\mathrm{a}}$ ditolak dan $\mathrm{H}_{0}$ diterima.

\section{HASIL DAN PEMBAHASAN}

Karakteristik Responden

Tabel 1

Distribusi Frekuensi Berdasarkan Usia, Interaksi Teman Sebaya dan Perilaku Merokok Remaja Putra Kelas IX di SMP Dawan Klungkung

\begin{tabular}{lcc}
\hline \multicolumn{1}{c}{ Variabel } & Frekuensi (n) & Persentase (\%) \\
\hline Usia & & \\
14 Tahun (Remaja Awal) & 59 & $46,5 \%$ \\
15 Tahun (Remaja Tengah) & 68 & $53,5 \%$ \\
Interaksi Teman Sebaya & & \\
Tidak Terpengaruh & 8 & $6,3 \%$ \\
Terpengaruh & 119 & $93,7 \%$ \\
Perilaku Merokok & & \\
Rendah & 3 & $2,3 \%$ \\
Sedang & 33 & $26,0 \%$ \\
Tinggi & 91 & $71,7 \%$
\end{tabular}

Berdasarkan Tabel 1 menunjukkan bahwa sebagian besar responden berada pada usia 15 tahun (Remaja Tengah) yaitu sebanyak 68 responden (53,5\%) dengan terpengaruh interaksi teman sebaya yaitu sebanyak 119 responden $(93,7 \%)$, tabel 1 juga menunjukkan bahwa sebagian besar responden berperilaku merokok tinggi yaitu sebanyak 91 responden $(71,7 \%)$. 
Tabel 4

Hubungan Interaksi Teman Sebaya Dengan Perilaku Merokok Pada Remaja Putra Kelas IX di SMP Negeri Kecamatan Dawan Kabupaten Klungkung.

\begin{tabular}{|c|c|c|c|c|c|c|c|c|}
\hline \multirow{3}{*}{$\begin{array}{c}\text { Interaksi } \\
\text { Teman Sebaya }\end{array}$} & & & \multicolumn{4}{|c|}{ Perilaku Merokok } & \multirow{3}{*}{$\begin{array}{c}\text { Spearman } \\
\text { Rank } \\
\text { (p Value) }\end{array}$} & \multirow[t]{3}{*}{$\mathbf{r}$} \\
\hline & \multicolumn{2}{|c|}{ Rendah } & \multicolumn{2}{|c|}{ Sedang } & \multicolumn{2}{|c|}{ Tinggi } & & \\
\hline & $\mathrm{F}$ & $\%$ & $\mathrm{~F}$ & $\%$ & $\mathrm{~F}$ & $\%$ & & \\
\hline Tidak & 3 & 37,5 & 5 & 62,5 & 0 & 0 & $(0,000)$ & 0,458 \\
\hline Terpengaruh & & & & & & & & \\
\hline Terpengaruh & 0 & 0 & 28 & 23,5 & 91 & 76,5 & & \\
\hline
\end{tabular}

Tabel 4 diatas menunjukkan terdapat lima responden (62,5\%) dengan interaksi teman sebaya tidak terpengaruh dan berperilaku merokok sedang, serta terdapat 91 responden $(76,5 \%)$ dengan interaksi teman sebaya terpengaruh dengan perilaku merokok tinggi.

Hasil uji hipotesis berdasarkan output menggunakan SPSS, diperoleh bahwa nilai sig. (2-tailed) menggunakan uji korelasi spearman's rho atau rank spearman antara dua variabel yaitu sebesar $0,000<0,05$, artinya hipotesis pada penelitian ini $\mathrm{H}_{\mathrm{a}}$ diterima dan $\mathrm{H}_{0}$ ditolak. Hal ini menyatakan bahwa terdapat hubungan antara interaksi teman sebaya dengan perilaku merokok pada remaja putra di SMP Negeri Kecamatan Dawan Kabupaten Klungkung. Dimana koefisien korelasi antara kedua variabel sebesar 0,458 dan secara statistik hubungan antara interaksi teman sebaya dengan perilaku merokok pada remaja putra termasuk dalam kategori cukup kuat.

\section{PEMBAHASAN}

\section{Interaksi Teman Sebaya Pada Remaja Putra di SMP Negeri Kecamatan Dawan Kabupaten Klungkung}

Hasil analisa interaksi teman sebaya dengan perilaku merokok pada remaja putra di SMP Negeri Kecamatan Dawan Kabupaten Klungkung didapatkan sebanyak 119 $(93,7 \%)$ remaja putra terpengaruh oleh interaksi teman sebaya sedangkan delapan $(6,3 \%)$ remaja yang tidak terpengaruh oleh interaksi teman sebayanya. Berdasarkan data penelitian ini bahwa interaksi teman sebaya dapat mempengaruhi, mengubah, atau memperbaiki kelakuan individu antara dua orang atau lebih yang memiliki keadaan atau tingkat perkembangan yang setingkat dengan usia yang tidak harus sama. Dikutip dari teori Ali dalam Amin et al. (2016) teman sebaya memegang peranan penting dalam kehidupan remaja. Remaja sangat ingin diterima dan dipandang sebagai anggota kelompok teman sebayanya, baik di sekolah maupun diluar sekolah. Oleh karenanya, remaja cenderung bertingkah laku seperti tingkah laku teman sebayanya.

Adapun faktor-faktor yang mempengaruhi interaksi teman sebaya yang krusial pengaruhnya terhadap perilaku merokok pada remaja yang dirumuskan pada penelitian ini adalah berupa umur, jenis kelamin, pendidikan. Faktor umur pada interaksi teman sebaya sangat mudah dapat terpengaruh oleh kelompok karena pada usia remaja ini adalah masa pembuktian diri kepada orang lain, maka remaja akan melakukan apapun agar dirinya diakui oleh teman sebayanya walaupun apa yang ia lakukan sebenarnya salah. Hal ini sejalan dengan teori yang dikatakan oleh Monk's \& Blair dalam Wijayanti (2016) bahwa faktor yang cenderung menimbulkan munculnya interaksi teman sebaya pada remaja salah satunya umur, konformitas semakin besar dengan bertambahnya usia, terutama terjadi pada usia 15 tahun atau belasan tahun. Sementara itu interaksi teman 
sebaya dapat juga dipengaruhi oleh faktor jenis kelamin, kecenderungan laki laki untuk berinteraksi dengan teman sebayanya lebih besar dari pada anak perempuan.

Selain faktor umur dan jenis kelamin yang dapat mempegaruhi interaksi teman sebaya pada remaja, pendidikan juga dapat menjadi salah satu faktornya dimana pendidikan yang tinggi adalah faktor dalam interaksi teman sebaya karena orang yang berpendidikan tinggi mempunyai wawasan dan pengetahuan luas yang akan mendukung dalam pergaulannya.

Pada dasarnya peranan teman sebaya bagi remaja adalah dapat memberikan kesempatan bagi remaja untuk belajar bagaimana berinteraksi dengan orang lain, belajar mengontrol tingkah laku sosial, belajar mengembangkan keterampilan, dan minat yang relevan dengan usianya, serta belajar saling bertukar perasaan dan masalah. Dikutip dari teori Yusuf dalam Amin et al. (2016) bahwa peranan dan fungsi interaksi teman sebaya sangat erat kaitanyya dengan kelompok remaja ,dengan adanya perkembangan proses sosialisasi. Individu mencari kelompok yang sesuai dengan keinginan, bisa saling berinteraksi satu sama lain dan merasa diterima dalam kelompok. Pada penelitian ini bahwa pada kenyataanya interaksi teman sebaya sangat berperan dan mempengaruhi perilaku merokok. Karena interaksi teman sebaya cenderung mengajak individu satu sama lain untuk merokok.

\section{Perilaku Merokok Pada Remaja Putra di SMP Negeri Kecamatan Dawan Kabupaten Klungkung}

Berdasarkan data kuisoner yang telah dikumpulkan, dari 127 responden yang terlibat dalam penelitian ini tiga diantaranya berperilaku merokok rendah, 33 diantaranya berperilaku merokok sedang, dan 91 lainnya berperilaku merokok tinggi. Dari data tersebut, dapat disimpulkan bahwa tingkat perilaku merokok dengan frekuensi terbanyak adalah perilaku merokok tinggi dengan persentase $71,7 \%$.

Dalam penelitian ini dapat disimpulkan bahwa usia seseorang dengan interaksi teman sebaya juga dapat berpengaruh terhadap perilaku merokok remaja. Berkaitan dengan usia, dikutip dari teori Saktyowati dalam Wijayati (2014) dinyatakan bahwa usia paling rawan seseorang untuk memulai merokok adalah usia remaja (10-19 tahun). Dimana usia ini merupakan remaja dengan peralihan dari anak-anak menuju dewasa. Pada masa remaja, umumnya remaja suka mencoba-coba hal yang baru, meskipun belum tahu akibatnya. Hal ini sesuai dengan data kuisoner yang menunjukkan bahwa responden pada usia 15 tahun (remaja tengah) adalah usia yang paling banyak mengalami pengaruh perilaku merokok dengan persentase $53,5 \%$, sedangkan usia yang paling sedikit terpengaruh adalah responden usia 14 tahun (remaja awal) dengan persentase $46,5 \%$.

Sementara itu, berkaitan dengan interaksi teman sebaya dapat diketahui bahwa semakin banyak remaja merokok maka semakin besar kemungkinan teman-temannya adalah perokok juga dan demikian sebaliknya. Penelitian Saktyowati dalam Wijayati (2014) mengatakan ada dua kemungkinan yang terjadi, pertama remaja terpengaruh oleh teman-temannya atau bahkan remaja tersebut dipengaruhi oleh diri remaja tersebut yang akhirnya mereka semua menjadi perokok. Remaja perokok mempunyai sekurangkurangnya satu atau lebih sahabat yang perokok begitu pula dengan remaja non perokok. Hal ini bisa dilihat dari hasil penelitian yang menunjukkan bahwa sebagian besar responden yang terpengaruh terhadap interaksi teman sebaya yang berperilaku merokok tinggi dengan persentase $71,7 \%$ sementara itu responden yang terpengaruh terhadap interaksi teman sebaya yang berperilaku merokok rendah dengan persentase 
2,3\%. Ini menunjukkan bahwa tingat interaksi teman sebaya memang memiliki pengaruh terhadap perilaku merokok pada remaja karena perilaku merokok pada remaja ini bukan karena untuk mengendalikan perasaan mereka, melainkan karena sudah menjadi kebiasaan atau rutinitas individu maupun kelompok.

Perilaku merokok yang dilakukan oleh seseorang terutama remaja usia Sekolah Menengah Pertama (SMP), merupakan orang yang mencoba untuk merokok karena alasan ingin tahu atau ingin melepaskan diri dari rasa sakit fisik maupun jiwa dan membebaskan diri dari kebosanan. Merokok juga memberi image kepada remaja bahwa merokok dapat menunjukkan kejantanan (kebanganggaan diri), kedewasaan dan dapat diakui oleh teman sebaya atau kelompok. Individu juga merokok dengan alasan sebagai menghilangkan stress. Remaja mulai merokok berkaitan dengan adanya krisis psikososial yang dialami pada perkembangannya yaitu pada masa ketika mereka mencari jati diri (Saktyowati dalam Wijayati 2014).

\section{Hubungan Interaksi Teman Sebaya Dengan Perilaku Merokok Pada Remaja Putra di SMP Negeri Kecamatan Dawan Kabupaten Klungkung}

Berdasarkan hasil penelitian diketahui terdapat 91 responden $(76,5 \%)$ dengan interaksi teman sebaya terpengaruh dan berperilaku merokok tinggi serta terdapat 28 responden $(23,5 \%)$ dengan interaksi teman sebaya terpengaruh dan berperilaku merokok sedang. Dengan demikian hasil penelitian ini sesuai dengan teori yang dikemukakan oleh Anam et al. (2019) bahwa terdapat pengaruh interaksi teman sebaya dengan perilaku merokok.

Hasil uji hipotesis berdasarkan output menggunakan SPSS, diperoleh bahwa nilai sig. (2-tailed) menggunakan uji korelasi spearman's rho atau rank spearman antara dua variabel yaitu sebesar $0,000<0,05$, artinya hipotesis pada penelitian ini $\mathrm{H}_{\mathrm{a}}$ diterima dan $\mathrm{H}_{0}$ ditolak. Hal ini menyatakan bahwa terdapat hubungan antara interaksi teman sebaya dengan perilaku merokok pada remaja putra di SMP Negeri Kecamatan Dawan Kabupaten Klungkung. Sesuai dengan pendapat Sari et al. (2016) yang mengatakan bahwa hubungan antara interaksi teman sebaya yang dapat terpengaruh terhadap perilaku merokok karena adanya penerimaan tanpa syarat terhadap lingkungan sebayanya. Biasanya remaja ditandai dengan emosi yang masih labil sehingga demi diterimanya seorang individu dalam suatu kelompok ia akan melakukan apapun yang diperintahkan oleh kelompok teman sebayanya, sedangkan kondisi ini dapat diinterpretasikan bahwa interaksi teman sebaya pada remaja atau siswa tersebut tergolong sangat terpengaruh. Dimana koefisien korelasi antara kedua variabel sebesar 0,458 dan secara statistik hubungan antara interaksi teman sebaya dengan perilaku merokok pada remaja putra termasuk dalam kategori cukup kuat. Nilai korelasi sebesar 0,458 menurut Sugiyono (2017) berarti ada hubungan yang signifikan antara hubungan interaksi teman sebaya dengan perilaku merokok pada remaja putra di SMP Negeri Kecamatan Dawan Kabupaten Klungkung.

Dalam hal ini penelitian sebelumya yang mendukung hasil dari analisis yang telah dilakukan pada penelitian ini yaitu Penelitian Anam et al. (2019), yang bertujuan untuk mengetahui hubungan pengetahuan dan sikap dengan perilaku merokok pada siswa laki-laki Madrasah Aliyah Pangeran Antasari Martapura Kabupaten Banjar Tahun 2018 sebanyak 63 orang siswa, dimana penelitian ini menunjukkan perilaku merokok siswa bahwa sebagian besar responden tidak merokok yaitu sebanyak 38 orang $(60,3 \%)$ setelah dilakukan uji statistik menggunakan uji chi square dengan kesimpulan hasil yang didapatkan ada hubungan pengetahuan dengan perilaku merokok pada siswa laki- 
laki dengan nilai p-value yang didapatkan $(0,008<0,05)$ serta ada hubungan sikap dengan perilaku merokok pada siswa laki-laki dengan nilai $\mathrm{p}$-value yang didapatkan $(0,000<0,05)$. Serta penelitian yang dilakukan oleh Adhyastama (2015) yang melakukan penelitian dengan judul hubungan interaksi teman sebaya dengan penyesuain sosial pada siswa dengan hasil yang didapat pada penelitian ini diperoleh koefisien korelasi sebesar 0,523; $\mathrm{p}=0,000(\mathrm{p}<0,01)$. Dari ketiga hasil penelitian tersebut dapat disimpulkan bahwa interaksi teman sebaya dapat mempengaruhi perilaku remaja salah satunya yaitu perilaku merokok yang paling banyak dilakukan oleh remaja putra utamnya pada kalangan SMP.

\section{SIMPULAN DAN SARAN \\ Simpulan}

Interaksi teman sebaya memiliki peran besar dalam mempengaruhi perilaku merokok remaja akibat dari tata pergaulan yang berlaku di kalangan remaja. Hal ini tidak terlepas dari rasa ingin diterima remaja di kalangan teman sebayanya, sehingga remaja akan mengikuti arus dari cara bergaul di lingkungannya terutama teman sebayanya.

\section{Saran}

Sehubungan dengan hasil penelitian masih ada remaja yang memiliki perilaku merokok tinggi, oleh karena itu peneliti mengharapkan kepada peneliti selanjutnya agar dapat memperluas faktor yang mempengaruhi interaksi teman sebaya dengan perilaku merokok serta diharapkan mampu memperbaiki kelemahan-kelemahan yang terdapat dalam penelitian ini dan dapat menggunakan variabel-variabel lain yang mempengaruhi perilaku merokok.

\section{DAFTAR PUSTAKA}

Adhyastama, A. A. (2015). Hubungan Antara Interaksi Teman Sebaya Dengan Penyesuaian Sosial Pada Siswa. E-Journal, 1. http://eprints.ums.ac.id/34393/1/02. Naskah Publikasi.pdf

Amin, L. N., Hasyim, A., \& Yanzi, H. (2016). Pengaruh Hubungan Sosial Teman Sebaya terhadap Pilihan Melanjutkan Pendidikan Ke-smpn 5. Jurnal Kultur Demokrasi, 4(2). http://jurnal.fkip.unila.ac.id/index.php/JKD/article/download/10870/7499

Aminullah, S. D. A. (2018). Perilaku Merokok Pada Siswa SMP Negeri Ternate Kabupaten Alor Provinsi Nusa Tenggara Timur. Mitra Sehat, 87-92. https://scholar.google.co.id/scholar?hl=id\&as_sdt=0\%2C5\&q=aminullah+merokok +pada+siswa+smp\&btnG=\#d=gs_qabs\&u=\%23p\%3Dnb0OENWWAJ0J

Anam, K., M., B. I., \& Raudah. (2019). Hubungan Pengetahuan dan Sikap dengan Perilaku Merokok Pada Siswa Laki-Laki Madrasah Aliyah Pangeran Antasari Martapura Kabupaten Banjar Tahun 2018. 5(2), 89-92. https://rumahjurnal.net/sagacious/article/download/689/422

Dewi, H. E. (2012). Memahami Perkembangan Fisik Remaja. Gosyen Publishing.

Dinkes, K. K. (2019). Data PISPK Tahun 2018.

Dinkes, P. B. (2018). Data Riset Kesehatan Dasar Provinsi Bali 2018.

Fauziyyah, L. A. (2019). Hubungan Teman Sebaya dan Efikasi Diri Terhadap Perilaku Merokok Remaja Pada Siswa Laki-Laki di SMPN 13 Padang Tahun 2018. ESkipsi. http://scholar.unand.ac.id 
Hidayat, A. A. A. (2014). Metode Penelitian Keperawatan dan Teknik Analisa Data. Salemba Medika.

I, P. D. J. (2012). Kesehatan Remaja Problem dan Solusinya (Edisi 2). Salemba Medika.

Jumiyanti, Yusmansyah, \& Widiastuti, R. (2015). HUBUNGAN INTERAKSI TEMAN SEBAYA DAN MOTIVASI BELAJAR DENGAN PRESTASI BELAJAR SISWA SMP. Journal of Chemical Information and Modeling, 53(9), 1689-1699. https://doi.org/10.1017/CBO9781107415324.004

Kurniafitri, D. (2015). Perilaku merokok pada perempuan di perkotaan. Kurniafitri, Devi, $\quad 2 \quad$ Nomor $\quad .2, \quad 1-15$. https://jom.unri.ac.id/index.php/JOMFSIP/article/download/7361/7038

Lailatul, R., Febriana, S., \& Darwin, K. (2015). Faktor Pendukung Dan Penghambat Intensi Remaja Berhenti Merokok. Cybrarians Journal, 2(37), 1-31. https://doi.org/10.12816/0013114

Martin, G., \& Pear, J. (2015). Modifikasi Perilaku Makna dan Penerapannya (Cet. 1). Pustaka Pelajar.

Murisal, M. (2012). Pengaruh Kelompok Teman Sebaya Terhadap perilaku Konsumtif Pada Remaja Putri. 2, 2. http://id.portalgaruda.org/?ref=browse \&mod=viewarticle \&article=158388

Notoadmojo, P. D. S. (2018). Metodologi Penelitian Kesehatan. Rineka Cipta.

Notoatmodjo, S. (2017). Promosi Kesehatan Dan Ilmu Perilaku (Edisi 2). Rineka Cipta.

Novita, N., \& Franciska, Y. (2013). Promosi Kesehatan Dalam Pelayanan Kebidanan. Salemba Medika.

Noviyeni. (2019). Hubungan Tingkat Kecemasan dan Perilaku Merokok Dengan Kejadian Insomnia Pada Mahasiswa Angkatan 2012 Fakultas Teknik. 4-5. http://scholar.unand.ac.id/21874/1/Abstrak Noviyeni wtmrk.pdf

Nursalam. (2015). Metodologi Penelitian Ilmu Keperawatan: Pendekatan Praktis (Edisi 4). Salemba Medika.

Ratnaningsih, T., Indatul, S., \& Peni, T. (2019). Buku Ajar ( Teori dan Konsep ) Tumbuh Kembang dan Stimulasi bayi, Toddler, Pra Sekolah, Usia Sekolah dan Remaja. In Indomedia Pustaka (pertama). Indomedia Pustaka.

Regina, Sutrisno, H., \& Muntaha. (2015). HUBUNGAN INTERAKSI SOSIALTEMAN SEBAYA DENGAN PERILAKU SOSIAL ANAK DI PENDIDIKAN ANAK USIA DINI SENTOSA PONTIANAK http://repository.unmuhpnk.ac.id/103/1/JURNAL REGINA.pdf

Riskesdas. (2018). Hasil Riset Kesehatan Dasar Tahun 2018. Badan Penelitian dan pengembangan kesehatan Kementrian Republik Indonesia. https://www.kemkes.go.id/resources/download/info-terkini/hasil-riskesdas2918.pdf

Riyanto, A. (2015). Pengolahan dan Analisis Data Kesehatan (Kedua). Nuha Medika.

Santrock, J. W. (2017). Remaja (Ke-11 Jili). Erlangga.

Saputro, K. Z. (2018). Memahami Ciri dan Tugas Perkembangan Masa Remaja. Aplikasia: Jurnal Aplikasi Ilmu-Ilmu Agama, 17(1), 25. https://doi.org/10.14421/aplikasia.v17i1.1362

Sari, A., Firdaus, S., \& Andri, M. (2016). HUBUNGAN PESAN IKLAN "MEROKOK MEMBUNUHMU” DENGAN PERILAKU MEROKOK PADA SISWA DI SMP NEGERI 29 BANJARMASIN. Advances in Applied Mathematics, 7(060005012), 
1. https://doi.org/10.1016/j.aam.2008.09.001

Soetjiningsih. (2018). Tumbuh Kembang Anak dan Remaja. sagung seto.

Sugiyono. (2017). Metode Penelitian Kuantitatif, Kualitatif, dan R\&D. Alfabeta.

Suharno. (2016). Hubungan Teman Sebaya Dengan Perilaku Merokok Pada Remaja Di

Desa Sukahaji Wilayah Kerja Uptd Puskesmas Sukahaji Kabupaten Majalengka

Tahun 2016. E-Journal, 2-3. http://ejournal.stikesypib.ac.id/file.php?file=preview_jurnal\&id=575\&cd=0b2173f

f6ad6a6fb09c95f6d50001df6\&name=Suharno-HUBUNGAN TEMAN SEBAYA DENGAN PERILAKU MEROKOK PADA REMAJA DI DESA SUKAHAJI WILAYAH KERJA UPTD PUSKESMAS SUKAHAJI KABUPATEN MAJALENGKA TAH

Surodjo, B., \& Langi, S. S. (2013). Stop Smoking For Good Rakyat Sehat Negara Kuat. PT. Gramedia Pustaka Utama.

Tulenan, M., Rompas, S., \& Ismanto, A. (2015). Hubungan Perilaku Merokok Dengan Prestasi Belajar Pada Remaja Perokok Di Sma Negeri 1 Remboken. Jurnal $\begin{array}{lll}\text { Keperawatan UNSRAT, } & 3(2), & 109235 .\end{array}$ https://ejournal.unsrat.ac.id/index.php/jkp/article/download/8031/7591

WHO. (2015). Global Youth Tobacco Survey (GYTS). Indonesia Report. http://www.searo.who.int/tobacco/documents/ino_gyts_report_2014.pdf.

Widyawathi, A. . T. A., Arta, S. K., \& Surasta, I. W. (2014). FAKTOR-FAKTOR YANG BERHUBUNGAN DENGAN PERILAKU MEROKOK PADA SISWA KELAS X DI SMKN 5 DENPASAR. Jurnal Ilmu Keperawatan Unud, 2-3. https://ojs.unud.ac.id/index.php/coping/article/download/10016/18834

Wijayanti, A. K. (2016). HUBUNGAN INTERAKSI TEMAN SEBAYA DENGAN PERILAKU KONSUMTIF PADA SISWA KELAS XI DI SMA N 6 YOGYAKARTA.

7-8. http://journal.student.uny.ac.id/ojs/index.php/fipbk/article/download/882/808

Wijayati, C. (2014). Gambaran faktor yang mempengaruhi remaja merokok di kecamatan sipispis kabupaten serdang bedagai. http://scholar.unand.ac.id/21874/

Yatim, D. I. (2015). Siapakah Remaja Itu? (Irwanto (ed.); Seri Genre). Badan Kependudukan dan Keluarga Berencana Nasional. 